\title{
Cechy komunikacji elektronicznej
}

\section{Marta Dąbrowska}

Uniwersytet Jagielloński w Krakowie md_doc@interia.pl

\begin{abstract}
Streszczenie
Współczesne media elektroniczne stały się celem licznych badań językoznawczych. Niniejsza analiza dotyczy jednej z najpopularniejszych ich odmian - krótkiej wiadomości tekstowej. 160 prywatnych SMSów, zarówno w języku polskim, jak i angielskim przebadano pod względem ich cech formalnych, skupiając się głównie na aspekcie redukcji tekstu pod względem obecności bądź eliminacji elementów fatycznych, szczególnie zwrotów adresatywnych, powitań, pożegnań oraz emotikonów, a także interpunkcji. Badanie przeprowadzone również $w$ odniesieniu do wcześniejszej analizy wiadomości mailowych wykazało znaczny procent eliminacji elementów konwencjonalnych tekstu $w$ SMSach $w$ porównaniu z mailami, szczególnie zwrotów adresatywnych i powitań, redukcje formalna zwrotów pożegnalnych oraz omijanie znaków przystankowych, pokazując tym samym, jak dużo elementów w komunikacie jest redundantnych. Analiza wykazała również widoczne różnice między SMSami polskimi $i$ angielskimi, zwłaszcza pod względem frekwencji takich elementów, jak podpis, zwrot pożegnalny, użycie emotikonów oraz skracanie wyrazów, które znacznie częściej występowaty w tekstach angielskich niz polskich.
\end{abstract}

Słowa kluczowe: komunikacja elektroniczna, SMS, email, redukcja tekstu, redundancja

Abstract

Features of Electronic Communication

Contemporary electronic media have become a frequent object of linguistic research. The present analysis concerns one of its most popular manifestations - the short text message. 160 private text messages, both Polish and English, have been investigated in terms of their formal features, with a focus placed mainly on the aspect of text reduction with respect to the presence or absence of its phatic elements, primarily forms of address, greetings, leave-takings, emoticons as well as punctuation. The analysis conducted also with reference to an earlier investigation of the electronic mail has demonstrated a significant percentage of the conventional text elements elimination in text messages in comparison to emails, especially of forms of address and greetings, a formal reduction of leave-taking formulas as well as the 
omission of punctuation, this way indicating how many elements of communication appear to be redundant. The analysis has also shown visible differences between Polish and English text messages, particularly in terms of the frequency of the use of such aspects as the signature, the leave-taking formula, the use of emoticons and word abbreviations, which appear to be a more typical element of English rather than Polish text messages.

Keywords: electronic communication, text messages, email, text reduction, redundance

\section{Wstęp}

W ciągu ostatniej dekady ogromną popularność w dziedzinie komunikacji międzyludzkiej zdobyły nowe gatunki wypowiedzi, które przenoszone są za pośrednictwem urządzeń elektronicznych. Można się nawet pokusić o tezę, że komunikacja elektroniczna zdominowała życie codzienne znacznego procentu społeczeństwa, dyskontując takie formy komunikowania się, jak list, pocztówka, gazeta, książka, a nawet do pewnego stopnia rozmowa telefoniczna. $\mathrm{O}$ tym, iż media elektroniczne mają tak istotny wpływ na porozumiewanie się w dzisiejszym społeczeństwie, świadczyć mogą coraz liczniejsze publikacje oraz analizy tego zagadnienia, i to nie tylko na temat czysto technicznych aspektów wykorzystania tychże środków komunikacji (por. Dąbrowska 1999, 2000; Erickson 1996; Herring 1996a; Mulholland 1999; MtuTay 1995; Sproull, Kiesler 1986; Walther i in. 1994).

Jedną z głównych cech, które znacząco odróżniają media elektroniczne od tradycyjnych form porozumiewania się za pomocą pisma, jest redukcja tekstu (Mulholland 1999), co wyraźnie pokazuje, jak wiele jest w języku codziennej komunikacji elementów zbędnych. W moim artykule traktującym o e-mailu jako o hybrydzie mowy i pisma (Dąbrowska 2000) analizowałam już różnorodne cechy poczty elektronicznej w jej odniesieniu do tradycyjnego listu. W obecnych rozważaniach chciałabym się skupić przede wszystkim na wyżej wspomnianej kwestii minimalizacji tekstu, i to w odniesieniu do innej, niepoddanej jeszcze szczegółowej analizie formie komunikacji elektronicznej, a mianowicie wiadomości tekstowej, znanej powszechnie jako SMS.

Problem ograniczenia długości, a co za tym idzie, także zawartości tekstu, do niezbędnego minimum jest znacznie bardziej widoczny w przypadku SMS-a niż e-maila z tej prostej przyczyny, iż SMS posiada ograniczoną liczbę znaków, jaką można zawrzeć w pojedynczej wiadomości $(160)^{1}$, podczas gdy e-maile, choć zwykle krótkie, takiego ograniczenia nie mają. W mojej analizie zajmę się SMS-em prywatnym, tzn. pominięte zostaną tutaj wiadomości, oferty i informacje oficjalne wysyłane przez operatorów sieci. Do dyskusji nie zostaną włączone również SMS-y nadawane za pośrednictwem Internetu, gdyż jako teksty. o znacznie 
mniej ograniczonej długości nie będą one uznawane przeze mnie za SMS-y prototypowe. Omawiane przykłady pochodzą z puli 160 SMS-ów otrzymanych przeze mnie na przestrzeni 5 miesięcy, zarówno w języku polskim (113 wiadomości), jak i w bardziej ograniczonym stopniu w języku angielskim (47 wiadomości). Analizując wyżej wspomniany problem minimalizacji tekstu skupię się na kilku kwestiach, których większość została także omówiona w mojej dyskusji na temat listu elektronicznego, a mianowicie na obecności bądź braku takich elementów, jak zwrot powitalny wraz z formą adresatywną, zwrot pożegnalny czy też pozdrowienie, podpis nadawcy, a ponadto formalność języka, użycie małych bądź wielkich liter, występowanie skrótów i emotikonów, w przypadku języka polskiego stosowanie zwrotów i wyrazów obcojęzycznych, głównie angielskich, oraz ewentualne błędy ortograficznogramatyczne. Zwrócona przy tym zostanie szczególna uwaga na wykorzystanie elementów grzeczności językowej, czyli takich, które - jak twierdzą Brown i Levinson (1994: 25) występują w języku jako zbędne. Można by się zatem spodziewać, że będą one raczej pomijane w tak krótkich tekstach, jak SMS, podobnie jak inne niepotrzebne elementy typu powitanie czy pożegnanie. Rzeczywiście, wcześniej wspomniana analiza tekstu e-maila pokazała, że podobne akty mowy występowały w zebranym materiale sporadycznie (np. 7 przeproszeń czy podziękowań na 110 listów). Warto tu jednak zacytować Mulholland (1994, 1999, za Murray, 1995), która podkreśla, że wbrew przypuszczeniom, mimo redukowania wielu elementów składowych listu tradycyjnego, wyznaczniki grzeczności wcale nie zanikają, przeciwnie, czasem częstotliwość ich użycia wzrasta, jeśli istnieje niebezpieczeństwo, że odbiorca może nie być pewien, jak zdefiniować siłę illokucyjną wypowiedzi (por. Searle 1969). Mulholland zauważa również, iż wyznaczniki grzeczności w e-mailach ograniczają się zwykle do najprostszych zwrotów typu please, $O K$. Analiza tekstów SMS da nam okazję, aby porównać w tym kontekście obydwa gatunki wypowiedzi i zaobserwować zachowania typowe pod tym względem dla użytkowników języka polskiego.

Czy rzeczywiście zatem w tak krótkich komunikatach, jakimi są SMS-y, jeden z głównych aspektów, jaki zostaje wyeliminowany, czy też znacznie ograniczony, to zwroty grzecznościowe lub elementy, które funkcjonują jako nośniki grzeczności konwencjonalnej, czyli formalnej, w odróżnieniu od nieformalnej, czyli takiej, której celem jest podtrzymanie dobrych, solidarnych ${ }^{2}$ stosunków między nadawcą a adresatem? (por. Dąbrowska, 2001; Janney, Arndt, 1992). Do przejawów grzeczności konwencjonalnej zaliczam m.in. takie akty mowy, jak powitania (włączając tutaj zwrot adresatywny), pożegnania, podziękowania, przeproszenia, życzenia, gratulacje, komplementy itd., czyli innymi słowy typowe zwroty grzecznościowe pierwszorzędne. Termin ten wprowadziłam w odniesieniu do wyrażeń, 
których celem podstawowym jest sprawić przyjemność adresatowi, w odróżnieniu od zwrotów drugorzędnych, jak np. odmowa, opinia, sugestia itp., tj. aktów mowy, które mogą być wyrażane grzecznie i zwykle są, aczkolwiek ich celem zasadniczym nie jest li tylko wywoływanie pozytywnych odczuć u odbiorcy (por. Dąbrowska, 2001)³. Jeśli chodzi o akty mowy typu podziękowanie, przeproszenie, zaproszenie, prośba itp., trudno analizować stopień ich redukcji w zebranych SMS-ach w sposób systematyczny, gdyż zależy to od indywidualnego charakteru i celu wiadomości oraz jej zawartości; liczba odpowiednich przykładów także nie byłaby wystarczająca, aby poczynić tu wiążące obserwacje. $Z$ tej przyczyny w mojej analizie skupię się jedynie na kilku na typowych elementach składowych listu tradycyjnego, tj. na powitaniach, obejmujących także zwroty adresatywne oraz pozdrowieniach-pożegnaniach i podpisie. Przyjrzyjmy się zatem, czy któreś z wyżej wymienionych podlegają szczególnej redukcji i jaki jest ich procentowy udział w ogólnej puli analizowanych komunikatów.

Powitanie - jeden z podstawowych elementów grzeczności konwencjonalnej, typowo występuje w połączeniu ze zwrotem apelatywnym. Jeśli chodzi o ten ostatni, jego obecność w tekście SMS-a jest rzeczywiście elementem zbędnym, kiedy zdamy sobie sprawę z faktu, że adresatem takiego komunikatu jest w przeważającej mierze właśnie ta osoba, z której numerem telefonu się łączymy. Użycie takiego zwrotu ma natomiast sens, kiedy adresatem wiadomości jest ktoś jeszcze: członek rodziny, znajomy itp., z którym właściciel telefonu jest z jakiegoś powodu w danym przypadku łączony. Uznać zatem należy, że pojawienie się niepotrzebnego i wykorzystującego przecież pewien procent ograniczonej długości komunikatu apelatywu w SMS-ie, który adresowany jest do posiadacza telefonu, musi być przejawem grzeczności ze strony piszącego, może też dodatkowo podkreślać inwokacyjny charakter wypowiedzi, czyli innymi słowy, przenosić na tekst pisany cechy języka mówionego, tak jak zaobserwowałam to już w przypadku listu elektronicznego. Analiza procentowa zebranego materiału w języku polskim pokazuje, iż rzeczywiście występowanie zwrotów adresatywnych jest stosunkowo niewielkie (łącznie 14\% wszystkich SMS-ów), z czego najbardziej typowe jest użycie formy podstawowej imienia w wołaczu: Marto (68\% wszystkich apelatywów), pozostałe to forma mianownika bądź też zdrobniała i humorystyczna forma w wołaczu, np. Marciu! ${ }^{4}$. Odmiennie przedstawia się sytuacja w przypadku materiału angielskiego - tutaj 53\% komunikatów rozpoczynało się od apelatywu, i co również warte podkreślenia, wśród nich aż $85 \%$ poprzedzone było konwencjonalnym, grzecznościowym słowem dear ('drogi'). Jest to zwrot typowy dla korespondencji listowej w języku angielskim, natomiast $\mathrm{w}$ zebranym materiale polskim zdecydowanie brak jego 
funkcjonalnego odpowiednika. Może to stanowić potwierdzenie zaobserwowanego przeze mnie w analizie grzeczności językowej faktu, iż respondenci anglojęzyczni w większym stopniu przestrzegają zasad grzeczności konwencjonalnej niż respondenci polscy (por. Dąbrowska 2001).

Zwrot adresatywny bywa typową częścią składową nadrzędnego wobec niego powitania, a czasem go w całości zastępuje. W obliczu konieczności ograniczania długości wiadomości tekstowej można ponownie założyć, że występowanie powitania, jako zwrotu bez konkretnej wartości informacyjnej, będzie tu również ograniczone. I rzeczywiście, w przypadku SMS-a powitania zostały prawie całkowicie wyeliminowane, co dało się zauważyć szczególnie w tekstach polskich. Wystąpiły tam one w niewiele ponad 3\% wiadomości, z czego zaledwie połowa to typowe polskie Cześć!, a pozostałe to raczej zwroty niekonwencjonalne i zależne od idiolektu piszącego. Dla porównania, w tekstach e-maila zwroty powitalne zanotowano w $34 \%$ przypadków. W SMS-ach anglojęzycznych udział procentowy powitań ponownie okazuje się być nieco wyższy, bo wystąpiły one w 18\% przypadków. $64 \%$ z nich to jednak bardzo typowe i krótkie Hi!, pozostałe to Hello! lub Good morning!

Poza powitaniem innym zwyczajowym elementem listu tradycyjnego, a także w ogromnej mierze, bo w $99 \%$ analizowanego przeze mnie materiału, listu elektronicznego (Dąbrowska 2000) jest podpis, który okazjonalnie przejmuje także funkcję pożegnania, choć zwykle jest jednym z jego elementów. Podobnie, jak w przypadku powitania, podpis w komunikacie SMS-owym jest rzeczą z reguły niepotrzebną, gdyż odbiorca otrzymując wiadomość umie zidentyfikować nadawcę poprzez numer jego telefonu, najczęściej również nadawca jest osobą dobrze odbiorcy znaną i jako taka często figuruje w jego telefonicznej książce adresowej pod konkretnym imieniem czy identyfikatorem. Oczywiście, podpis jest elementem niezbędnym, gdy wiadomość jest przesyłana drogą internetową, która nie identyfikuje nadawcy poprzez imię lub numer telefonu, lub też gdy SMS wysyła osoba nieznana, to ostatnie jednak zgodnie z niepisanymi zasadami etykiety rzadko ma miejsce. Procentowo wyższa częstotliwość podpisu w SMS-ie w stosunku do zwrotu adresatywnego (22\% wiadomości w języku polskim i aż 62\% w języku angielskim) wskazuje jednak na to, że nadawcy czują się bardziej w obowiązku przestrzegać tej zasady grzeczności, która nakazuje autorowi komunikatu podać swą tożsamość. Aczkolwiek zauważyć tutaj trzeba, że jedynie część podpisów to faktycznie imię w pełnej lub zdrobniałej formie $(60 \%$ podpisów polskich i jedynie $21 \%$ angielskich nazwisk jako takich nie zanotowano, co zrozumiałe w przypadku korespondencji prywatnej). Pozostałe to wersje skrócone do minimum, najczęściej do samych inicjałów (od imienia inazwiska, np. $B B, G S z$ lub tylko imienia, np. $M$, SiM), czasem 
do pseudonimu (np. Art) - nie zajmują one wiele miejsca, a jednocześnie są zrozumiałe dla odbiorcy. Ciekawą strategię dało się zaobserwować w przypadku respondenta anglojęzycznego, który skrócił swoje imię John do wersji $J n$.

Procentowy udział zwrotów pożegnalnych w analizowanych SMS-ach przedstawiał się podobnie, jak w przypadku samych podpisów - w języku polskim 28\% nadawców wykorzystało ten czysto grzecznościowy element (dla porównania, w e-mailach zwrotów pożegnalnych użyło 33\% nadawców), aw języku angielskim 66\%: Zauważmy jednak, że w języku polskim najczęściej (85\%) występowały pozdrowienia jednowyrazowe, charakterystyczne dla języka polskiego, bez zbędnych przysłówków emfatycznych - typowo był to zwrot Pozdrawiam (34\% pożegnań), obcojęzyczne wyrażenie Postrowy (10\%), oraz w pojedynczych przypadkach takie nieformalne zwroty, jak Pozdrowienia, Buziaki, Buziaczki, Buźka, Trzymaj się, Do zobaczenia, Dobranoc. Z uwagi na swój skrótowy charakter na szczególną uwagę zasługują tu także formy typu Pozdrówka czy też pozdr., pzdr oraz wymienione już wyżej Postrowy. Można pod tym względem zauważyć sporą różnicę między SMS-em a e-mailem, wktórym przeważały jednak formy rozbudowane, co widać było także w przypadku samych podpisów. Wspomnieć tu też trzeba o elementach obcojęzycznych, w zebranym materiale głównie angielskich, które czasem także pojawiały się w miejsce pożegnań polskich, np. Bye bye, See you, Take care, Hugs. Ich obecność jest z pewnością odbiciem bliskiej zażyłości między nadawcą a odbiorcą, elementem tzw. 'języka grupy', niewątpliwiejednak znaczną rolę w doborze form obcych mogła mieć również długość tego typu wyrażeń, w przypadku języka angielskiego prawie zawsze krótszych. Porównanie długości formuł pożegnalnych wskazuje na dość znaczną różnicę pomiędzy komunikatami w języku polskim i angielskim w tych ostatnich w formie pożegnań częściej występowały zwroty więcej niż jednowyrazowe, ale mimo swej złożoności były one ciągle jednak stosunkowo krótkie (wszystkie należy zaliczyć do wyrażeń typowych i nieformalnych). I tak, oprócz jednowyrazowego Love (10\%), dominował charakterystyczny dla angielskiego zwrot Much love (33\%), Take care (20\%) oraz w bardziej ograniczonej liczbie Have a nice day/evening, Good night, Enjoy the evening.

Wspominając wykorzystanie języka angielskiego do wyrażenia pożegnania, często w skrótowej formie, nie można nie odnotować stosowania słów czy wyrażeń angielskich także w pozostałej treści komunikatu. W SMS-ach prywatnych po raz kolejny podkreślają one bliską i nieformalną relację między korespondentami opartą na solidarności, są też one znacznie bardziej skrótowym sposobem przekazywania informacji. Oprócz tego bowiem, że wyrazy angielskie są na ogół krótsze od polskich, język ten w komunikacji nieformalnej 
pozwala na pomijanie elementów niepotrzebnych, takich jak zaimki, niektóre czasowniki bądź ich części składowe. W materiale polskim zanotowano dość liczne elementy angielskie, w tym również przykłady powyższej strategii upraszczania, np. Milej drogi back; Zobacz please na moja mail;... przed Big Day...; Dzięki za SMS-wishes, the same to you; Please, co mam jeść? ; All ill; Me too, bit late, looked for same papers; Will be back home after 9 PM; Wish you a good weekend; Calls expected. Upraszczanie gramatyki $w$ języku nieformalnym udało się zaobserwować na przykładzie SMS-ów od nadawców anglojęzycznych, którzy często wykorzystuja te możliwości, np. Will wait to hear from u..., Hope you are well..., Wish I was there..., Am out..., Just woke up..., Just curious... (brak zaimka i/lub czasownika). Jednakże wzorce pisania SMS-ów w języku angielskim nie zostały przetransponowane na grunt polski całkowicie, jakkolwiek wydawałoby się, że kolejny aspekt języka angielskiego, o którym będzie tutaj mowa, byłby bardzo użyteczny dla korespondentów polskich, zwłaszcza tych posługujących się językiem angielskim stosunkowo swobodnie. Angielski oferuje bowiem liczne możliwości wykorzystania skrótów, pojedynczych liter bądź cyfr zamiast pełnobrzmiących wyrazów (należą one do specjalnego kodu języka elektronicznego, o którym wspomnę poniżej), co oczywiście znacznie minimalizuje długość tekstu. Oto kilka przykładów:

$$
\begin{array}{ll}
>_{-} \text {thx/tnx-thanks } & >- \text { yday/yes 'day yesterday } \\
>_{-} \text {u-you } & >- \text { pis-please } \\
>_{-} \text {ur -your } & >- \text { rt-right } \\
>_{-} \text {r are } & >- \text { wd would } \\
>_{-} 4-\text { for } & >- \text { wio-without } \\
>_{-}-\text {- to } & >- \text { ASAP-as soon as possible } \\
>_{-} \text {msg-message } & >-G N-\text { good night }
\end{array}
$$

oraz kilka wyrażeń z ich wykorzystaniem: Whatr u up 2 2day?, Pis Xplain, Thx 2 u, Yday I managed 2 drop u a few lines, Thx 4 ur msg. Tego typu import z języka angielskiego jest bardzo rzadki (yes 'day, v. bad, OK bądź też fonetyczne $O K I$, copy r), dają się jednak odnotować przypadki skrótów w materiale polskim, często tworzonych ad hoc, np. Dzięki za info dot. pana K.; Dzięki za tel.; Jeśli jesteś w Wawie; Jeśli będziesz w Pad., Wyślę progr wykładu, pzdr. Niewątpliwą trudnością, jaką napotykają w tym przypadku korespondenci polscy są wielosylabowe wyrazy, a przede wszystkim nasz rozbudowany system fleksyjny. 
Omawiając cechy typowe SMS-a, nie sposób pominąć aspektu bardzo charakterystycznego dla komunikacji elektronicznej w ogóle, a mianowicie emotikonów czy też piktogramów, których podgrupy to stosowane często „smileys”, czyli „buźki”, „uśmieszki” oraz wspomniane powyżej skróty. W przypadku SMS-a użycie piktogramów spełnia podwójną rolę, nie tylko bowiem pozwala w sposób graficzny oddać uczucia i nastrój piszącego, ale także, ze względu na potrzebę minimalizacji tekstu, może znacznie bardziej skrótowo i efektywnie oddać intencje nadawcy. Wydawać by się zatem mogło, że jest to bardzo popularny sposób przekazywania emocji iinformacji, szczególnie iż zarówno w Internecie, jak i na rynku dostępne są nawet obszerne listy piktogramów (np. „Odtajniony kod SMS-owy” operatora sieci Era). W zebranym przeze mnie materiale rzeczywiście występują pewne przykłady emotikonów, np. pojawiające się zwłaszcza jako element pożegnalny komunikatu $x x x, x o x o x,)$, ;), ich użycie jednak, zwłaszcza przez nadawców polskojęzycznych, jest bardzo sporadyczne, prawdopodobnie ze względu na jednak stosunkowo niewielką znajomość tego kodu wśród osób nie będących stałymi użytkownikami tzw. czatu. W przypadku listów anglojęzycznych użycie piktogramów, przynajmniej tych najpopularniejszych, jest bardziej widoczne - przeprowadzona analiza zanotowała ich obecność w 50\% SMS-ów.

Elementem wypunktowanym w mojej analizie tekstu listu elektronicznego była modyfikacja pisowni tekstu w języku polskim polegająca na uproszczeniu polskich znaków diakrytycznych, oraz znaczna ilość błędów, tzw. literówek, co podkreślało dużą nieformalność e-maila. Naturalnie w przypadku SMS-a polskie znaki diakrytyczne również nie występują, a mimo to tekst jest zawsze zrozumiały dla odbiorcy. Wynika z tego zatem, że polskie diakrytyki to kolejny 'zbędny' element w języku pisanym, jakkolwiek brak polskich znaków nie przyczynia się tutaj do minimalizacji rozmiarów tekstu. Jeśli chodzi o błędy w pisowni, w odróżnieniu od języka e-maila w SMS-ach błędy takie występują bardzo rzadko. Trudno dokładnie odgadnąć przyczynę tej różnicy, można jednak przypuszczać, iż fakt że nadawca zmuszony jest wystukiwać z wielką uwagą znaki na niewielkich rozmiarów klawiaturze, gdzie pod każdym przyciskiem kryje się kilka możliwości, sprawia, że komponowanie tekstu odbywa się ze znacznie większą precyzją. Natomiast stosunkowo nowym aspektem, zwłaszcza w polskojęzycznej komunikacji elektronicznej jest coraz częstsze użycie małych liter tam, gdzie ortografia nakazuje stosowanie dużych. Jest to moda od kilku lat dość już rozpowszechniona w języku angielskim, zwłaszcza wśród korespondentów młodszej generacji. Niewątpliwie jednym z powodów jest chęć zaznaczenia własnej odrębności i buntu wobec narzuconych kanonów; jest też rzeczą prawdopodobną, że w przypadku 
komunikacji elektronicznej w ogóle, z natury pośpiesznej, spełniającej rolę zastępczą w stosunku do kontaktu bezpośredniego, unikanie dużych liter jest po prostu strategią oszczędzającą czas. Przykłady tego typu dały się zauważyć w obu językach, np. john, thomas, marta, $i$ am sure, valentine, jurek, jw, nowy kleparz, bądź też użycie małych liter na początku nowego zdania, choć - ponownie - ich liczba była znacznie mniejsza niż w przypadku e-maila.

$\mathrm{Na}$ koniec wymienić należy jeszcze jedną strategię, która wydaje się być charakterystycznajedynie dla komunikatu SMS, przynajmniej w pewnych jej aspektach. Rzecz dotyczy interpunkcji, a raczej generalnej tendencji do jej upraszczania bądź maksymalnego unikania. Widać to szczególnie w języku polskim, gdzie użycie znaków przestankowych jest bardziej rozbudowane. Redukcja interpunkcji odnosi się przede wszystkim do przecinków, które jako elementy niepotrzebnie zabierające miejsce wydają się być zbędne, np. Dzięki niestety X będzie...; Niestety nie mogę; Jestem $w$ Warszawie wracam jutro; Znów nie wiem czy będziemy; Jeszcze jedno w programie trzeba umieścić bankiet z niespodzianka OK?; Ceny OK ale X miat jeszcze spytać o plakaty faks dostałem chyba OK. Z uwagi na to, że nie tylko przecinki, ale i kropki zabierają cenne w wiadomości SMS miejsce, bardzo częstym zabiegiem piszącego jest całkowita rezygnacja z interpunkcji i zaznaczanie nowego zdania jedynie przez wielkie litery: OK Jeszcze do ciebie zadzwonię EB; Marto No przecież wiem U mnie to samo Zadzwonie $w$ weekend X; Jest OK Piotr będzie na czas Pozdrawiam X. Alternatywą do takiego podejścia, którego konsekwentne stosowanie zostało zaobserwowane w przypadku jednego z piszących, jest natomiast wstawianie kropek pomiędzy wszystkie wyrazy, niezależnie od tego, czy jest to początek zdania, czy też nie. W praktyce zajmuje to tyle samo miejsca, co unikanie interpunkcji w ogóle, czyni to jednak komunikat mniej przejrzystym, np.

Y Marto!Jeszcze.zdążymy.wypić.tę.kawę.ale.oczywiście.szkoda.że.nie.będzie.to.

w.środę.czy.możesz.mi.powiedzieć.ile.kosztuje.strona.tlumaczenia?

W podsumowaniu tej krótkiej analizy nowej formykomunikacji, jaką jest krótka wiadomość tekstowa, zauważyć trzeba, że podkreśla ona bardzo wyraźnie, jak wiele elementów w języku jest niepotrzebnych z punktu widzenia efektywnego przekazu informacji. Przeciwstawnym biegunem takiego komunikatu jest przekazywanie treści przy wykorzystaniu kanału mówionego, czy to poprzez rozmowę, czy też prelekcję. Istnienie tak dużej liczby elementów zbędnych przejawia się bardzo dobitnie np. w procesie tłumaczenia ustnego, szczególnie symultanicznego, gdzie - z konieczności podyktowanej ograniczeniami czasowymi - tłumacz 
jest w stanie przekazać treść oryginału w znacznie bardziej zwięzłej formie (por. Alexieva 1992, Setton 1999). Podobnie, choć w znacznie większym stopniu, rzecz ma się w przypadku SMS-a, gdzie techniczne ograniczenie długości komunikatu jest znacznie bardziej rygorystyczne. Stąd też tak duży, choć nie całkowity, stopień redukcji różnych elementów przekazu, między innymi również tradycyjnych form grzecznościowych tekstu pisanego. Czy wobec tego etykieta językowa jest zbędna? Oczywiście nie, pomaga ona bowiem zachować tak kruche przecież podstawy porozumienia między ludźmi, nawet jeśli jest ona tylko konwencją, a jej brakjest bardziej zauważalny niż jej obecność (por. Murray 1995). Zauważmy jednak, że w komunikacie typu SMS dominuje nacisk na treść, nie formę, zgodnie z jedną z zasad kompetencji pragmatycznej Lakoff (1973/1974) „Wyrażaj się jasno”, która przeważa nad zasadą uprzejmości „Wyrażaj się grzecznie”, kiedy są po temu odpowiednie okoliczności. Czy jednak cytowane tu SMS-y były oznaką braku etykiety? W większości tak, ale etykiety konwencjonalnej. Tutaj zastąpiona została ona wspomnianą już na początku grzecznością niekonwencjonalną, której zadaniem jest podtrzymywanie dobrych stosunków między ludźmi poprzez relacje oparte na solidarności, a te z kolei mogą przejawiać się poprzez rezygnację z konwencji na rzecz przejrzystości, zrozumiałości i bezpośredniości wypowiedzi, co wyraźnie widać zwłaszcza w zebranym materiale polskim.

\section{Przypisy}

${ }^{1} \mathrm{~W}$ chwili obecnej znajduje się na rynku jeden model telefonu, który jest $\mathrm{w}$ stanie automatycznie podzielić zbyt długą wiadomość tekstową na dwa kolejno po sobie następujące SMS-y.

2 Pojęcie „solidarny” odnosi się tutaj do rozróżnienia pomiędzy „mocą, władzą” (ang. ,power”), tzn. relacją, w której jedna ze stron dominuje nad drugą pod względem hierarchii, statusu, wieku, co odzwierciedla się w formalności języka, a „solidarnością” (ang. „solidarity”), czyli utrzymaniem dobrych stosunków między rozmówcami opartych na relacji równości i familiarności (Brown, Gilman 1960).

3 Szerzej o tym rozróżnieniu piszę w swojej nieopublikowanej pracy doktorskiej pt. Selected Expressions of Politeness in English and Polish. A Sociolinguistic Study (2001).

${ }^{4} \mathrm{~W}$ analizie listów elektronicznych zwrot adresatywny pojawił się znacznie częściej, bo w ok. 50\% e-maili (Dąbrowska 2000).

\section{Źródło}

Tekst ten został po raz pierwszy opublikowany w roku $2002 \mathrm{w}$ tomie Nowe oblicza komunikacji we współczesnej polszczyźnie pod redakcją Grzegorza Szpili, Język a komunikacja 4 (tom 1): Kraków: Tertium; 151-160. 


\section{Bibliografia}

Alexieva, Bistra (1992) "The optimum text in simultaneous interpreting: a cognitive approach to interpreting training." [W:] Cay Dollerup, Anne Loddegaard (red.), Translation and Interpreting. Training, Talent and Experience Teaching. Amsterdam, Filadelfia: J. Benjamins Publishing Company; 221-230.

Brown, Penelope, Stephen C. Levinson ([1987] 1994) Politeness. Some Universals in Language Usage, Cambridge: Cambridge University Press.

Brown, Roger, Albert Gilman (1960) "The pronouns of power and solidarity.” [W:] Thomas, A. Sebeok (red.), Style in Language. Nowy Jork i Londyn: The Technology Press of Massachusetts Institute of Technology and John Wiley \& Sons; 435-449.

Dąbrowska, Marta (1999) “Selected expressions of politeness in e-mail English.” [W:] Jan Arabski (red.), PASE Papers in Language Studies. Proceedings of the Seventh Annual Conference of the Polish Association of the Study of English, Szczyrk, May 1998. Katowice: Para; 81-90.

Dąbrowska, Marta (2000) „Język e-maila jako hybryda mowy i pisma”. [W:] Grzegorz Szpila (red.), Język trzeciego tysiąclecia, Seria: Język a komunikacja 1. Kraków: Tertium; 95-111.

Dąbrowska, Marta (2001) Selected Expressions of Politeness in English and Polish. A Sociolinguistic Study. Nieopublikowana praca doktorska.

Erickson, Thomas (1996) "Social interaction on the net: virtual community as participatory genre." [W:] Robert Sprague (red.), Proceedings of the Thirteenth Annual Hawaii International Conference on System Sciences, tom 1, Maui, Hawaii: IEEE; 13-21.

Herring, Susan C. (red.) (1996) Computer-mediated Communication. Linguistic, Social and Cross-cultural Perspectives. Pragmatics and Beyond, New Series 39. Amsterdam, Filadelfia: John Benjamins Publishing Company.

Janney, Richard W., Horst Arndt (1992) "Intracultural tact versus intercultural tact." [W:] Richard J. Watts, Sachiko Ide, Konrad Ehlich (red.), Politeness in Language. Studies in its History, Theory and Practice. Berlin, Nowy Jork: Mouton de Gruyter; 21-42.

Lakoff, Robin T. (1973) “The logic of politeness or minding your p's and q's.” [W:] Claudia W. Corum, Thomas C. Smith-Stark, Ann Weiser (red.), Papers from the Ninth Regional Meeting of the Chicago Linguistic Society. Chicago: Chicago Linguistic Society; 292305. 
Lakoff, Robin T. (1974) "What you can do with words: politeness, pragmatics, and performatives." [W:] Charles Fillmore, George Lakoff, Robin Lakoff (red.) Berkeley Studies in Syntax and Semantics XVI, tom 1, Berkeley: Department of Linguistic and Institute of Human Learning, University of California; 1-55.

Mulholland, Joann (1994) Handbook of Persuasive Tactics. Londyn: Routledge.

Mulholland, Joann (1999) "E-mail: uses, issues, and problems in an institutional setting." [W:] Francesca Bargiela-Chappini, Catherine Nickerson (red.) Writing Business: Genres, Media and Discourse, Harlow: Longman; 57-84.

Murray, Denise E. (1995) Knowledge Machines: Language and Information in a Technological Society. Boston: Addison-Wesley Longman.

Searle, John R. (1969) Speech Acts. Cambridge: Cambridge University Press.

Setton, Robin (1999) Simultaneous Interpretation. A Cognitive-Pragmatic Analysis. Amsterdam, Filadelfia: John Benjamins.

Sproull, Lee, Sara Kiesler (1986) "Reducing social context cues: electronic mail in organizational communication.” Management Science 32; 1492-1512,

Walther, Joseph B., Jeffrey F. Anderson, David W. Park (1994) "Interpersonal effects in computer-mediated interaction: a meta-analysis of social and antisocial communication." Communication Research 21 (4); 460- 487. 